\title{
EFFECT OF THERMAL ENVIRONMENT ON WATER AND FEED INTAKES IN RELATIONSHIP WITH GROWTH OF BUFFALO CALVES
}

\author{
G. Ashour ${ }^{1}$, F.I. Omran' ${ }^{2}$, M.M. Yousef ${ }^{2}$ and M.M. Shafie ${ }^{1}$ \\ 1- Department of Animal Production, Faculty of Agriculture, Cairo University, \\ Giza, Egypt 2- Department of Buffalo Research, Animal Production Research \\ Institute, Dokki, Egypt
}

\section{SUMMARY}

Eight buffalo calves, of six months of age with an average weight of $118 \mathrm{~kg}$, were used to compare and assess their water and feed intakes and the average daily weight gain in response to constant heat stress $\left(40{ }^{\circ} \mathrm{C}\right)$ and comfort $\left(25{ }^{\circ} \mathrm{C}\right)$ conditions in thermo-controlled labs. The calves were divided into two groups in two labs, 4 calves under $40{ }^{\circ} \mathrm{C}$ and $87.5 \%$ relative humidity (group, A) and 4 calves under $25{ }^{\circ} \mathrm{C}$ and $64 \%$ relative humidity. Two stages were studied, each of one month interrupted by 15 days outdoors interval between the two stages. The mean values of daily water (WI) and feed (FI) intakes were computed for weekly intervals during the experimental stages. The animals were weighed initially and finally at each stage to calculate the average daily gain $(A D G)$. The daily WI during the $1^{\text {st }}$ stage was greater under $40{ }^{\circ} \mathrm{C}$ by $20 \%$ than that under $25^{\circ} \mathrm{C}$, whereas the contrary occurred during the $2^{\text {nd }}$ stage. On the other hand, the FI was distinctly reduced by the effect of heat stress during the two stages in both concentrates and roughage. This effect of heat stress was great during the $1^{\text {st }}$ stage. The ADG in group (A) showed clear decrease (- $0.49 \mathrm{~kg} /$ day) in BW during the $1^{\text {st }}$ stage while in the $2^{\text {nd }}$ stage there was almost maintenance of BW. In clear contrast, group (B) showed great increase in $B W\left(1.11 \mathrm{~kg} /\right.$ day) during the $1^{\text {st }}$ stage however the increase in the $2^{\text {nd }}$ stage was lower $(0.45 \mathrm{~kg} /$ day). This study revealed that the major effect of temperature on growth is through control of FI. Under comfort temperature, in the $1^{\text {st }}$ stage the ADG increased positively with the increase in WI and FI, while in the $2^{\text {nd }}$ stage the calves showed less increase in spite of the increase in FI.

Keywords: Buffalo, calf body gain, water and feed intakes, heat stress

\section{INTRODUCTION}

Productive performance is the most important index out of various indices of animal's adaptability to environmental conditions. Among these indices, the average daily gain is the most indicative index from the growth and meat production point of view. This index is the outcome of water and feed intakes behaviour, which is affected, greatly by stress factors mainly that of climatic and nutritional conditions. Water and feed intakes are affected markedly by ambient temperature. The optimum, comfort, temperature is not the same for different bovines. Water intake

Issued by The Egyptian Society of Animal Production 
(WI) increased (Mullic, 1964; Ashour, 1990; Ashour et al., 1993; Omran, 1999 and Ashour et al., 2000), while feed intake (FI) decreased (Nangia and Garg, 1992; Omran, 1999 and Ashour et al., 2000), in response to rise of ambient temperature.

Growth performance deteriorated due to exposure to high air temperature or artificial heat stress experimentation (Kamal et al., 1972 \& 1989; El-Masry et al., 1989; Daader et al., 1989; Omran, 1999and Ashour et al., 2000).

Water buffaloes are potentially an important tropical bovine species, especially in very hot areas (Webster and Wilson, 1980). These authors concluded that it could compete very successfully with other bovine species, under harsh hot conditions. Cockrill (1974) stated that it would be effective, economically, to improve meat output from well-adapted buffaloes than to try to create favourable conditions for improved breeds of cattle.

The main objectives of the present study were to compare and assess the responses of buffalo calves $\left(6-9\right.$ mo) to constant heat conditions, stress $\left(40^{\circ} \mathrm{C}\right)$ and comfort $\left(25^{\circ} \mathrm{C}\right)$ in thermo-control labs (Artificial condition). The main intended responses were water and feed intakes and the average daily weight gain.

\section{MATERIAL AND METHODS}

The experimental work was carried out in the Animal Physiology Lab, Animal Production Department, Faculty of Agriculture, Cairo University, Egypt. Eight buffalo calves were available from Mahalet Mousa Farm, Animal Production Research Institute, Agriculture Research Center, Egypt.

At the beginning of the experiment the average age of the calves was six months, their live body weight ranged between $118-119.25 \mathrm{~kg}$. The calves were divided randomly into 2 labs, 4 under $40^{\circ} \mathrm{C}$ (group A) and 4 under $25^{\circ} \mathrm{C}$ (group B). The experimentation comprised two stages in the destined lab, each of one month, interrupted by 15 days outdoors interval between the two stages.

The experimental artificial indoors climates were fixed in the two labs $\left(\mathrm{A}, 40^{\circ} \mathrm{C}\right.$ and $\mathrm{B} 25^{\circ} \mathrm{C}$ ). Lab (A) was equipped by 4 heaters controlled by highly sensitive digital thermostat along with ceiling and suction fans. Thus the ambient temperature (AT) in this lab was fixed and maintained exactly at $40^{\circ} \mathrm{C}$ and the relative humidity (RH) \% was $87.7-87.3 \%$. Lab (B) was equipped by air conditioner and ceiling fan to maintain the temperature at $25^{\circ} \mathrm{C}$, the relative humidity $\mathrm{RH} \%$ ranged between 61.9 $67.3 \%$.

The ambient temperature during the outdoors interval (August) was $33^{\circ} \mathrm{C}$ at $08: 00 \mathrm{~h}$ and $37.42^{\circ} \mathrm{C}$ at $14: 00 \mathrm{~h}$ the relative humidity was $88.5 \%$ at $08: 00 \mathrm{~h}$ and 77.0 $\%$ at $14: 00 \mathrm{~h}$.

The calves were fed and watered equally in both labs and outdoors according to the experimental procedure. Drinking fresh water was offered and recorded twice a day. The mean values of daily water and feed intakes were computed at weekly intervals during the experimental stages. A commercial concentrate ration was offered twice a day at 08:00 $\mathrm{h}$ and 15:00 h, it was offered in surplus amount every day to determine the free will daily feed intake (FI). Roughage (wheat straw and berseem , Egyptian clover, hay) was accessible all the day to determine the daily intake of each type. The concentrate ration was starter during the $1^{\text {st }}$ stage and 
growing ration till the end of the experiment. The nutrients in concentrates and roughage are indicated in table (1)

Table 1. Nutrients percentages in the ration components, on dry bases

\begin{tabular}{lccccc}
\hline \multicolumn{1}{c}{ Nutrients } & $\begin{array}{c}\text { Crude } \\
\text { protein }\end{array}$ & Crude fat & Crude fiber & Ash & NFE \\
\hline Starter Conc. & 21.40 & 5.26 & 11.45 & 10.70 & 51.19 \\
Growing Conc. & 16.40 & 4.80 & 16.53 & 12.70 & 49.57 \\
Wheat straw & 3.90 & 2.03 & 45.20 & 9.93 & 38.94 \\
Berseem Hay & 12.95 & 3.88 & 32.30 & 12.00 & 38.87 \\
\hline
\end{tabular}

The animals were weighted initially and finally at each stage, the following equation was used to calculate the average daily gain (ADG).

ADG $=$ (final weight - initial weight) $/$ number of days.

The data were analyzed by least squares analysis of variance using the General Linear Models Procedure of the Statistical Analysis System (SAS, 2000) according to the following two models:

Model 1 for analyses of factors affecting water intake.

Where:

$$
\mathbf{Y}_{\mathrm{ijklm}}=\mu+\mathbf{T}_{\mathrm{i}}+\mathbf{b}_{1}\left(\mathbf{W}_{\mathrm{j}}\right)+\mathbf{b}_{2}\left(\mathbf{C}_{\mathrm{k}}\right)+\mathbf{b}_{3}\left(\mathbf{R}_{\mathrm{l}}\right)+(\mathbf{T W})_{\mathrm{ij}}+\mathbf{e}_{\mathrm{ijklm}}
$$

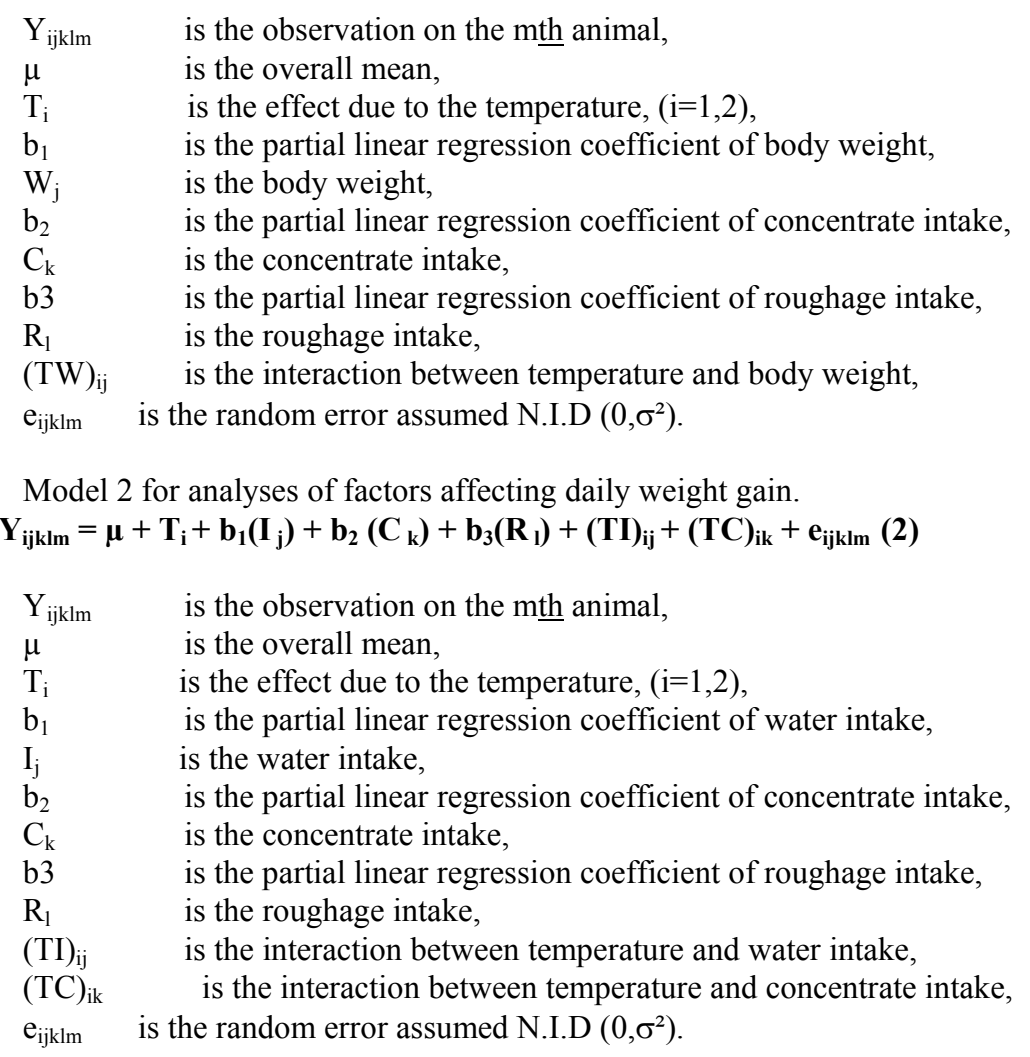




\section{RESULTS AND DISCUSSIONS}

\section{Water intake}

The daily water intake (WI) during the $1^{\text {st }}$ stage was more under heat stress by 20 $\%$ over that under the comfort condition (Table 2 ), the contrary occurred during the $2^{\text {nd }}$ stage. This contradiction is mostly due to changes in live body weight (LBW) of group (B) as indicated in table (2).

Table 2. Mean Daily water intake (WI, L/h/day) and mean daily water intake related to metabolic body weight (MBW) (L/Mkg/day) for the two calves groups $\left(\mathrm{A}\right.$, under $40^{\circ} \mathrm{C}$ and $\mathrm{B}$ under $25^{\circ} \mathrm{C}$ ) during the two stages

\begin{tabular}{lcccc}
\hline & \multicolumn{2}{c}{$\mathbf{1}^{\text {st }}$ Stage } & \multicolumn{2}{c}{$\mathbf{2}^{\text {nd }}$ Stage } \\
\cline { 2 - 5 } Water intake (WI) & $(\mathbf{A})$ & $(\mathbf{B})$ & $(\mathbf{A})$ & $(\mathbf{B})$ \\
\hline $\mathrm{L} / \mathrm{h} /$ day & $21.14 \pm 1.50$ & $17.66 \pm 1.25$ & $22.95 \pm 1.95$ & $29.71 \pm 2.1$ \\
& & & & \\
$\mathrm{~L}_{\text {/ Mkg } / \text { day }^{*}}$ & $0.23 \pm 0.01^{\mathrm{b}}$ & $0.14 \pm 0.01^{\mathrm{c}}$ & $0.26 \pm 0.02^{\mathrm{a}}$ & $0.23 \pm 0.01^{\mathrm{b}}$ \\
\hline $\mathrm{L}$
\end{tabular}

Live Body Weight

$\begin{array}{lllll}(\mathrm{LBW}, \mathrm{kg})^{* *} & 119.3-104.5 & 118.0-151.3 & 106.0-106.8 & 153.5-167.0\end{array}$

In the same row, means with different superscripts are significantly different $(\mathrm{P}<0.05)$.

$*$ : Intake related to metabolic body weight $\left(\mathrm{W}^{0.82}\right)$

** : Initial and final weight for each group at each stage of one month.

The mean values of (WI) as related to metabolic body weight $\left(\mathrm{BW}^{0.82}\right)$ is reported in table (2). This table shows that the water intake was always more under heat stress, with augmented effect during the $1^{\text {st }}$ stage. Omran (1999) reported that constant heat stress in lab at $40^{\circ} \mathrm{C}$ increased water consumption per $\mathrm{kg} \mathrm{MBW} \mathrm{MB}^{0.75}$ by $16 \%$ in buffalo calves and $25 \%$ in Friesian calves. Mullick (1962) reported $50 \%$ increase in (WI) during Indian summer $\left(41^{\circ} \mathrm{C}\right)$ while Misra et al. (1963) reported $13.5 \%$ increase in (WI) by buffaloes unprotected from solar radiation at an ambient temperature of $34.2^{\circ} \mathrm{C}$. Bianca (1964) reported that increased (WI) during heat stress aid in maintaining the body core temperature by its direct cooling effect on the reticule-rumen. in Egypt, Ashour (1990) found that buffalo calves increased their (WI) in the summer than in the winter by two folds as absolute values (39.2 vs. 20.1 $\mathrm{L} /$ day) and by three times as relative values to metabolic body weight $\left(\mathrm{W}^{0.75}\right)$.

The increase in (WI) with hot condition is augmented by behavioral eagerness to gulp copious cold water. This increase reflects the physiological role of (WI) in counteracting heat stress by increasing water vaporization through skin and / or respiratory surface.

Table (3) shows the confounded effect on water intake by relevant factors, particularly ambient temperature and roughage intake. Anyhow concentrate intake did not show significant effect on (WI). There was no significance of water intake on weight . The interaction between weight and temperature showed significant

$(\mathrm{P} \leq 0.05)$ effect. 
Table 3. ANOVA for factors affecting water intake by buffalo calves

\begin{tabular}{|c|c|}
\hline Source of variation & Significance level \\
\hline Temperature $(\mathrm{T})$ & $* *$ \\
\hline Weight (W) & ns \\
\hline Concentrate intake (C) & ns \\
\hline Roughage intake (R) & $* * *$ \\
\hline Temperature*Weight (TW) & $*$ \\
\hline
\end{tabular}

\section{Feed intake}

Mean values of feed intake (FI) was distinctly reduced by the effect of heat stress during the two stages in both concentrates and roughage (Table 4). That effect of heat stress was great during the $1^{\text {st }}$ stage, most probably at younger age since the body weight of this group (A) was almost the same during the two stages. On the other hand, the physiological mechanisms may have played a role in the readjustment for maintenance of the body weight during the $2^{\text {nd }}$ stage (Table 4). The increase in (FI) of group (B) during the $2^{\text {nd }}$ stage seems to be merely in accordance with increase in live body weight.

Table 4. Mean daily feed intake (FI, kg/h/day) and mean daily Feed intake related to metabolic body weight $(\mathrm{MBW})(\mathrm{kg} / \mathrm{Mkg} / \mathrm{day})$ for the two calves groups $\left(\mathrm{A}\right.$, under $40^{\circ} \mathrm{C}$ and $\mathrm{B}$ under $\left.25^{\circ} \mathrm{C}\right)$ during the two stages

\begin{tabular}{ccccc} 
& \multicolumn{2}{c}{$\mathbf{1}^{\text {st }}$ Stage } & \multicolumn{2}{c}{$2^{\text {nd }}$ Stage } \\
\cline { 2 - 5 } & $(\mathbf{A})$ & $(\mathbf{B})$ & $(\mathbf{A})$ & $(\mathbf{B})$ \\
\hline Intake, kg/h/day : & $1.11 \pm 0.09^{\mathrm{d}}$ & $3.24 \pm 0.07^{\mathrm{b}}$ & $2.35 \pm 0.07^{\mathrm{c}}$ & $4.67 \pm 0.06^{\mathrm{a}}$ \\
Concentrate & & & & \\
Wheat straw & $0.66 \pm 0.03^{\mathrm{c}}$ & $1.10 \pm 0.04^{\mathrm{a}}$ & $0.50 \pm 0.01^{\mathrm{d}}$ & $1.00 \pm 0.00^{\mathrm{b}}$ \\
\hline Berseem hay & $0.25 \pm 0.02^{\mathrm{a}}$ & $0.31 \pm 0.02^{\mathrm{a}}$ & $0.19 \pm 0.01^{\mathrm{a}}$ & $0.28 \pm 0.02^{\mathrm{a}}$ \\
\hline Intake, kg/Mkg/day*: & & & & \\
\hline Concentrate & $0.03 \pm 0.002^{\mathrm{c}}$ & $0.08 \pm 0.004^{\mathrm{b}}$ & $0.07 \pm 0.004^{\mathrm{b}}$ & $0.10 \pm 0.002^{\mathrm{a}}$ \\
Roughage & $0.02 \pm 0.0^{\mathrm{b}}$ & $0.03 \pm 0.0007^{\mathrm{a}}$ & $0.01 \pm 0.0003^{\mathrm{c}}$ & $0.02 \pm 0.0005^{\mathrm{b}}$ \\
\hline
\end{tabular}

In the same row, means with different superscripts are significantly different $(\mathrm{P}<0.05) .{ }^{*}$ : Intake related to metabolic body weight $\left(\mathrm{W}^{0.75}\right)$

Niles et al. (1980) found that there was reduction in forage intake by Holestin cow, during summer. They postulated this response to diets high in fiber content resulted in higher acetate production during fermentation. Acetate metabolism results in, somewhat, higher heat increment than other VFA. Nangia and Gary (1992) reported that voluntary (FI) during months of higher air temperature was reduced to $40 \%$ as compared to that consumed during cooler months. Baile and Forbes (1974) suggested that the reduced (FI) in summer is due to direct effect of elevated temperature on the appetite center in the hypothalamus ventromedial nucleus resulting in reduction of the production of VFA which are the main energy source in ruminants. 
Baccari et al. (1990) found that thermal stress reduced the dry matter intake and the level of serum $\mathrm{T}_{3}$ in young buffalo bulls, this case was also reported by Omran (1999) and Ashour et al. (2000).

Table (4) shows that the difference in feed intake, as related to metabolic body weight $\left(\mathrm{BW}^{0.75}\right)$, was significant between the two group during both stages. Omran (1999) found that the concentrate intake was reduced by heat stress at $40^{\circ} \mathrm{C}$ in lab from that pre stress by $20 \%$ in buffaloes and $18 \%$ in Friesian calves. This feed intake as related to metabolic body weight showed that concentrate intake was reduced in response to heat stress, from that pre stress by $13 \%$ in buffaloes and $17 \%$ in Friesian per $\mathrm{kg} \mathrm{BW}^{0.75}$.

\section{Response of growth}

Average daily gain (ADG) of the buffalo calves of the two groups showed clear decrease $(-0.49 \mathrm{~kg} /$ day $)$ in weight of group (A) during the $1^{\text {st }}$ stage while in the $2^{\text {nd }}$ stage there was almost maintenance of body weight allover that month period, (Table 5). In clear contrast, group (B) showed great increase in weight $(1.11 \mathrm{~kg} /$ day $)$ during the $1^{\text {st }}$ stage, however the increase the $2^{\text {nd }}$ stage was lower $(0.45 \mathrm{~kg} / \mathrm{day})$.

Table 5. Average daily gain (ADG, kg/day) of the two calf groups (A \& B) during the two stages

\begin{tabular}{lcc}
\hline Items & $(\mathbf{A})$ & (B) \\
\hline $1^{\text {st }}$ Stage & $(-)^{*} 0.49 \pm 0.03$ & $1.11 \pm 0.07$ \\
$2^{\text {nd }}$ Stage & $0.03 \pm 0.12$ & $0.45 \pm 0.04$ \\
\hline
\end{tabular}

*: (-) Average daily loss in weight .

Omran (1999) reported that heat stress at $40^{\circ} \mathrm{C}$ in lab reduced the (ADG) more than the pre stress by $28 \%$ in buffalo calves and $21 \%$ in Friesian calves.

Table (6) shows the variation in (ADG) as induced by the studied factors. Ambient temperature, water intake and concentrate intake induced significant effects; however roughage intake had no significant effect. The interaction between water intake and temperature showed no significant effect while the interaction between concentrate intake and temperature had highly significant effect on (ADG). This contrast in that interactions proves that the major effect of temperature on growth is through control of (FI).

Table 6. ANOVA for factors affecting daily weight gain of these buffalo calves

\begin{tabular}{|c|c|}
\hline Source of variation & Significance level \\
\hline Temperature $(\mathrm{T})$ & $* * *$ \\
\hline Water intake (I) & $* *$ \\
\hline Concentrate intake (C) & $* *$ \\
\hline Roughage intake (R) & Ns \\
\hline \multicolumn{2}{|l|}{ Interaction : } \\
\hline Temperature* Water intake (TI) & ns \\
\hline Temperature*Concentrate intake (TC) & $* * *$ \\
\hline
\end{tabular}


Table (7) shows the relationship between both (WI) and (FI) with body weight (BW) only for group (B), that under the comfort temperature $\left(25^{\circ} \mathrm{C}\right)$. It is clear that the correlation coefficients were high during the $1^{\text {st }}$ stage meaning the (BW) increased with intake. In the $2^{\text {nd }}$ stage the calves showed less increase (Table 5) in spite of increase in (FI) (Table 4), could this be due to the lower level of the grow concentrate in that stage (Table 1).

Table 7. Correlation coefficients among body weight, concentrate, roughage and water intake under $25^{\circ} \mathrm{C}$ (Group B), above for the $1^{\text {st }}$ stage and below for the $2^{\text {nd }}$ stage.

\begin{tabular}{ccccc}
\hline & $\mathbf{W}$ & $\mathbf{C}$ & $\mathbf{R}$ & $\mathbf{W I}$ \\
\hline $\mathrm{W}$ & & $0.38^{*}$ & $0.66^{* * *}$ & $0.21 \mathrm{~ns}$ \\
$\mathrm{C}$ & $-0.001 \mathrm{~ns}$ & & $0.44^{* *}$ & $-0.06 \mathrm{~ns}$ \\
$\mathrm{R}$ & $-0.34 *$ & $-0.21 \mathrm{~ns}$ & & $0.52 * *$ \\
$\mathrm{WI}$ & $0.11 \mathrm{~ns}$ & $-0.32 *$ & $0.60 * * *$ & \\
\hline$*: \mathrm{P} \leq 0.05$ & $* *: \mathrm{P} \leq 0.01$ & $* * *: \mathrm{P} \leq 0.001$ & $\mathrm{~ns}: \mathrm{P}>0.05$ &
\end{tabular}

Table 8. ANOVA for factors affecting feed intake (concentrate and roughage) of buffalo calves

\begin{tabular}{|c|c|c|}
\hline \multirow[t]{2}{*}{ Source of variation } & \multicolumn{2}{|c|}{ Feed intake } \\
\hline & Concentrate & Roughage \\
\hline Temperature $(\mathrm{T})$ & $* * *$ & $* * *$ \\
\hline Weight (W) & $*$ & ns \\
\hline Water intake (I) & $* * *$ & $* * *$ \\
\hline Temperature*Weight (TW) & $* * *$ & $* *$ \\
\hline$* *: \mathrm{P} \leq 0.01$ & ns: $\mathrm{P}>0.05$ & \\
\hline
\end{tabular}

\section{REFERENCES}

Ashour, G., 1990. Water balance in bovine as related to heat regulation. Ph.D. Thesis, Fac. Agric., Cairo Univ., Giza, Egypt.

Ashour, G., H.M. Mourad, H. Khalifa and M. Shafie, 1993. Water balance in riverine buffaloes. III. Seasonal changes in water turnover as related to heat regulation. Egyptian J. Anim. Prod.

Ashour, G., L.R. Hassan, F.I. Omran and M.M. Shafie, 2000. Growth performance of buffalo and Friesian calves under natural climatic and steady heat stress conditions. J. Agric. Sc. Mansoura Univ., 25: 2503-2515.

Baccari, F. Jr., A.C. Blasi, M.R. Muniz and C.A. Fre, 1990. Effect of thermal stress on feed intake and serum triiodothyronine in young buffalo bulls. Pro. II World Buffalo Congress. 12-16 December, 1988, New Delhi. P. 139.

Baile, C.A. and J.M. Forbes, 1974. Control of feed intake and regulation of energy balance in ruminants. Physiol. Rev., 54 : 160.

Bianca, W., 1964. Thermoregulatory responses of the dehydrated ox to drinking cold and warm water in warm environment. Res. Vet. Sci., $5: 75$.

Bianca, W., 1965. Reviews of the progress of dairy science. Secttion A: Phsiology. Cattle in a hot environment. J. Dairy Res., $33: 291$. 
Cockrill, R.W., 1974. The Husbandry and Health of the Domestic Buffalo. FAO, Rome, Italy.

Daader, A.H., I.F.M. Marai, A.A. Habeeb and H.M. Yousef, 1989. Improvement of growth performance of Friesian calves under Egyptian sub-tropical conditions. 1Internal cooling technique using diuretics and drinking cool water. Proceedings of 3rd Egyptian British Conference on Animal, Fish and Poultry Production, Vol 2, Alexandria, Egypt, p. 595.

El-Bedawy, T.M., H.M. Murad, M.M. Shafie and S.M. Salem, 1994. Water intake of sheep as influenced by feed intake and environmental temperature. Egyptian J. Anim. Prods., 31: 329-335.

El-Masry, K.A., T.H. Kamal, A.I. Abolnaga and I.F. Marai, 1989. Daily body weight gain, total body solids and biochemical responses of Friesian calves to mineral mixture and urea during heat stress. Proc. $3^{\text {rd }}$ Egyptian-British Conf. On Anim., Fish and Poultry Prod., Alexandria Univ., Egypt, 7-10 Oct., 1989, PP. 643-648.

Kamal, T.H., S. Kotby and H.A. El-Fouly, 1972. Total body solids gain and thyroid activity as influenced by goitrogen, diurectics sprinkling and air cooling inheat stressed water buffaloes and Friesian. In: Isotopes Studies in the Physiology of Domestic Animals. Proc. IAEA/FAO/Vienna.

Kamal, T.H., K.A. El-Masry and A.M. Abdel-Samee, 1989. Influence of hot climate and spray cooling on daily body gain and thyroxine and cortisol levels of Friesian calves. Proc. Inter. Symp., Cairo, Egypt, 5-7 Nov., 1988, EAAP Publication No. 38: 180-182.

Misra, M.S., B.P. Cupta and A. Roy, 1963. Physiological reactions of buffalo-cows maintained in two different housing condition during summer months. Indian J. Dairy Sci., 16:203.

Mullick, D.N., 1962. A study on the metabolism of food nutrients in cattle and buffalo bulls under climatic stress. In Proc. Symp. Environ. Physiol. Psychol. Arid. Cond. UNESCO, New York, 137.

Mullick D.N., 1964. A study on the metabolism of food nutrients in cattle and buffalo bulls under climatic stress. Arid Zon. Res. 14: 137, Paris, UNESCO.

Nangia, O.P. and S.L. Gary, 1992. Environmental changes in the energy-yielding blood metabolites and their relation to voluntary feed intake in buffaloes. Indian J. Dairy Sci., 54 : 6.

Niles, M.A., R.J. Collier and W.J. Croom, 1980. Effect of heat stress on rumen and plasma metabolisms and plasma hormones concentrations of Holestin cow. J. Anim. Sci., 50: 152.

Omran Fayza, I., 1999. Physiological reaction and growth performance of buffaloes and Friesian calves to heat stress. M. Sc. Thesis, Fac. of Agric., Cairo Univ., Giza, Egypt.

Thompson, R.D., J.E. Johnson, C.P. Breidenstein, A.J. Cuidry and W.T. Burnett, 1963. Effect of hot conditions on adrenal cortical, thyroid and other metabolism responses of dairy heifers. J. Dairy Sci., $46: 227$.

Webster, C.C. and P.N. Wilson, 1980. Agriculture in The Tropics. ELBS and Longman Group, London, p. 15. 
تأثير البيئة الحارة على المستهلك من الماء والغذاء بالنسبة الى النمو في العجول الجاموسىى

جمال عاثور 1، فايزة عمران²، محمد يوسف2، محمد الثافعي1

1- قسم الإتتاج الحيواني، كلية الزراعة، جامعة القاهرة، الجبيزة، مصر، 2- قسم بحوث الجاموس، معهر بحوث الإنتاج الحيواني، الثاقيى، مصر النصر

إستخدم في هذه التجربة 8 عجول جاموسى عمر ها 6 شهور ووزنها 118 كجم وذللك التقدير ومقارنة

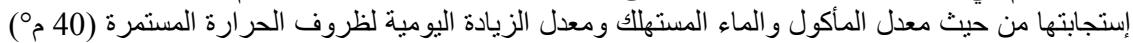

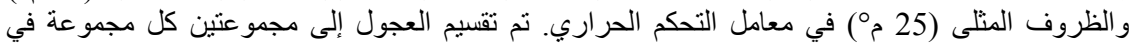

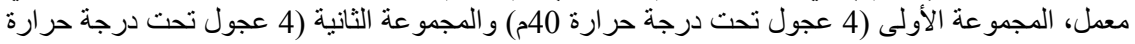

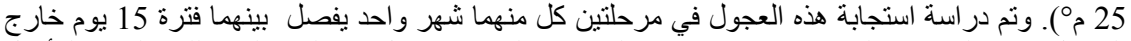

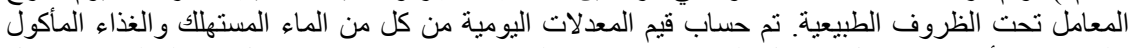

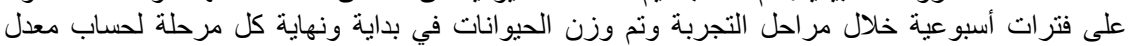

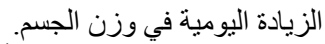

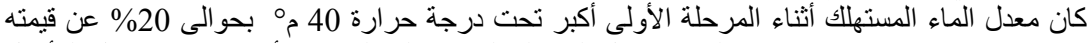

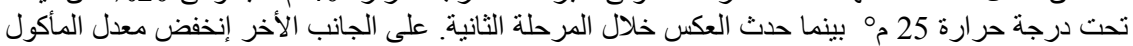

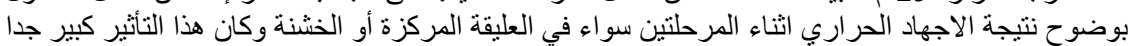

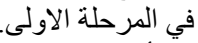

أظهرت الزيادة اليومية في وزن الجسم في المجموعة (أ) انخفاض واضح (0.49 كجم /يوم) اثناء المرحلة

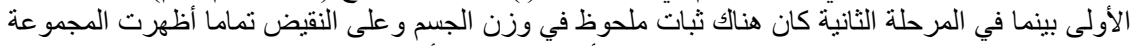

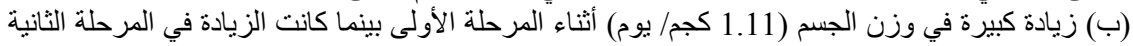

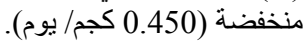

أظهرت هذه الدراسة أن الثأثير الاكبر للحرارة على كفاءة النمو يكون من خلال التحكم في معدل المأكول. تحت التحت

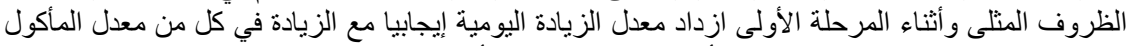

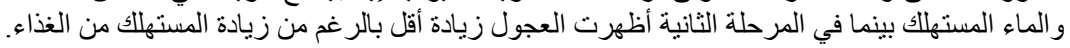

